\title{
Advantages and Reasons Hindering the Communication between Teachers and Parents: An Empirical Study
}

\author{
Panagiotis J. Stamatis, and Maria E. Chatzinikola
}

\section{ABSTRACT}

\begin{abstract}
This paper studies the advantages and reasons hindering communication between teachers and parents. Two hundred and twenty-two teachers and thirty-three primary school principals consider communication with parents important, because this communication creates a sense of security in students, improving their learning skills and conduct. Teachers consider that effective communication between teachers and parents benefits the school unit itself, contributing to its efficiency. The reasons hindering communication with parents mentioned by teachers include parents' lack of time to visit the school unit, parents' low social or education background, their children's poor performance or conduct. Teachers disagree that the education system structure constitutes a problem in their communication with parents, stressing that many parents do not understand the importance of their communication with the school unit attended by their children. Finally, teachers consider guidance plays an important part, as it helps mitigate the problems hindering efficient communication between teachers and parents.
\end{abstract}

Keywords: school, family, communication, primary education teachers' views

\section{INTRODUCTION}

Communication between teachers and parents in the Greek education environment creates a positive impact on both social institutions of school and family. Parents' participation in the education process is considered important when it takes place with a view of getting information about the child's learning progress, providing support to school activities and smooth operation (Castro et al., 2015; Wilder, 2014; Jeynes, 2016). According to studies, the benefits of communication between teachers and parents are reflected in the improvement of children's school performance (Houtenville \& Conway, 2008; Grace \& Gerdes, 2019; Tan et al., 2019; Otani, 2019), in the improvement of their conduct in the school environment but also at home (Mata et al., 2018), in their social adjustment (Epstein, 2018; Thompson et al., 2017) and in the achievement of the ultimate goal, which is children's academic success (Jeynes, 2015; Castro et al., 2015; Lawson, 2003).

In addition, parents' participation increases the interaction among parents, children and teachers based on mutual respect and understanding, leading to children's emotional and learning development (Mata et al., 2018). Building relationships of mutual respect between teachers and parents gives parents the possibility to understand teachers' role and the importance of their educational work for the social, emotional and learning development of their children (Owen, 2016). At the same time, teachers have the possibility to understand the diversity of families in terms of national and cultural origin (Epstein, 2018). Setting clear limits in the role of teachers and parents is also considered an essential factor. Teachers are considered responsible for the learning development of children, while parents are considered responsible for their social and emotional development (Stamatis \& Papanikolaou, 2017). However, there are teachers who give parents distinct, but equal, roles, sharing equally the responsibility for the learning skills and socialisation of children (Oostam \& Hooge, 2012).

Despite the advantages of communication between teachers and parents in the school environment, this is not always efficient. According to Ozmen et al. (2016), social and cultural differences between teachers and parents, parents' financial problems and their educational background contribute to parents' unwillingness to communicate with their children's teachers. The different way in which parents and teachers perceive parent-teacher communication and their different cognitive, social and cultural starting points create problems in the parent-teacher communication (Stamatis \& Nikolaou, 2020; Attanucci, 2004).

At theoretical level, in the past, many researchers tried to shape models about parents' participation in the learning process, differing from one another, depending on the participation in communication. International literature refers to the proposal of Epstein (2008), who mentions communication with parents as one of the overall six levels of autonomous parent participation. The remaining levels 
concern parents' help at home with guidance from school, voluntary work of parents in school activities and operation, assisting with homework, involvement of parents in parents' association and school management and contact of parents with actors form the local community and social services to support the educational work of the school.

According to Matsagouras \& Poulou (2009), the different way in which communication takes place between school and family is determined in the following theoretical models of communication between family and school:

1) School-centered model, which distinguishes the roles of school and family, assigning an educational role to the former and a role of upbringing and socialization to the latter.

2) Collaborative model, which imposes communication between teachers and family, with teachers defining the framework of this communication.

3) Negotiation model, which assigns to teachers and parents an equal part of involvement and

4) Family-centered model, which upgrades the role of parents and allows them to participate in decision-making, rendering them equal to teachers.

Communication between family and school environment, as an interactive relationship, is mentioned, among others, also in the following models of parent participation in the education process:

1) Ecosystemic model: Family and school interact as subsystems of the broader social system. These subsystems focus on the child. As the distance between them gets bigger, the relationships between them become more and more impersonal (Bronfenbrenner, 1986).

2) Comprehensive model: Family, school and social system interact and cooperate through three overlapping circles. The child is at their intersection (Epstein, 1995).

3) Model of Ryan \& Adams (1995): This modes studies to what extent the individual characteristics of the family members impact the child's conduct and school performance.

4) Model of Hoover-Dempsey et al. (2005): This model aims at understanding the reasons for which parents should be involved in the education of their children.

\section{METHODOLOGY}

The goal of this study is to investigate the views of principals and teachers of single grade primary schools of Rhodes about the advantages and reasons hindering communication between teachers and parents. Within this framework, the following research questions were asked in relation to the research aim:

1) What are the beneficial effects of communication between teachers and parents on students and the school unit itself?

2) What is the contribution of guidance to the management of communication between teachers and parents?

3) What are the reasons for the limited or insufficient communication of parents with the school unit attended by their children?

4) What are the teachers' views about the advantages and reasons hindering their communication with parents?

For the purposes of the research approach, the anonymous closed-ended written questionnaire was selected as the most appropriate means for collecting data, because it gives the interviewee the possibility to answer quickly, honesty and without the fear of direct control (Kidder \& Judd, 1986). The questionnaire used for this survey is divided into two parts. The first part concerns teachers' personal data and includes questions about their position at school, gender, age, years of experience and studies. The second part, which consists of closed-ended questions with five-level Likert scale responses, looks into: a) the beneficial effects of parents' participation in the education process and the role of guidance and $b)$ the reasons for the limited or insufficient communication between teachers and parents. Within the framework of conducting this survey, descriptive statistics indicators were study, both for the categorical variables (e.g. principals, elementary school teachers) and for the qualitative variables with a rating scale, such as frequency $(\mathrm{N})$, percentage in the total of cases (\%), average value (A), standard deviation (SD). To ascertain there is a correlation between a categorical variable (principals, elementary school teachers) and qualitative variables of rating scale, t-test of independent sample was applied. For the description of statistical significance $p$-value indicator was used $(p<0.01$ : Statistically strong relation, $\mathrm{p}<0.05$ : Statistically significant relation, $\mathrm{p}<0.1$ : Statistically weak relation) (Linardakis, 2014).

It is pointed out that to ascertain the degree of relevance categorical variables of 22-30 years and 51-60 years were selected for age and categorical variables 1-5 years and 26 and above years of experience were selected for the years of experience, in order to ascertain if there is convergence of views among young and senior teachers.

The survey questionnaire was administered to 35 school units which have 6 and/or more classrooms, in order to ensure that the responses of the sample are characterized by a comparable operation setting and school atmosphere. Responses to 255 questionnaires in total, by elementary school teachers (PE70) and principals, were collected. Most of the teachers who filled in the questionnaire were women, aged 41-60, with 16-20 and 26 and above years of experience. Most teachers stated as basic studies the university degree from the Department of Primary Education and as further studies the acquisition of a Master degree (Table 1).

TABLE I: PERSONAL DATA OF TEACHERS AND PRINCIPALS

\begin{tabular}{|c|c|c|c|}
\hline & & $\begin{array}{l}\text { Frequency } \\
\text { (N) }\end{array}$ & $\begin{array}{c}\text { Percentage } \\
(\%)\end{array}$ \\
\hline \multirow[b]{2}{*}{ Teachers } & Principals & 33 & 12.9 \\
\hline & Teachers PE70 & 222 & 87.1 \\
\hline \multirow[b]{2}{*}{ Gender } & Men & 71 & 27.8 \\
\hline & Women & 182 & 71.4 \\
\hline \multirow{4}{*}{ Age } & $22-30$ years old & 32 & 12.5 \\
\hline & $31-40$ years old & 65 & 25.5 \\
\hline & 41-50 years old & 84 & 32.9 \\
\hline & $51-60$ years old & 70 & 27.5 \\
\hline \multirow[t]{6}{*}{ Experience } & $1-5$ years & 31 & 12.2 \\
\hline & $6-10$ years & 26 & 10.2 \\
\hline & $11-15$ years & 56 & 22 \\
\hline & $16-20$ years & 59 & 23.1 \\
\hline & $21-25$ years & 28 & 11 \\
\hline & 26 years and above & 53 & 20.8 \\
\hline \multirow[t]{2}{*}{ Basic studies } & Pedagogical Academy * & 72 & 28.2 \\
\hline & $\begin{array}{l}\text { Department of Primary } \\
\text { Education *** }\end{array}$ & 179 & 70.2 \\
\hline \multirow[t]{3}{*}{ Further studies } & Master & 91 & 35.7 \\
\hline & PhD-Master & 19 & 7.5 \\
\hline & Did not answer & 64 & 25.1 \\
\hline
\end{tabular}

$* 2$ years of studies, $* * 4$ years of studies 


\section{RESULTS}

To the survey question "What are the beneficial effects of communication between teachers and parents on students and the school unit itself?", most principals and teachers responded that their communication with parents is helpful for the progress of children and improves their conduct, providing also the child with a sense of security. Most principals strongly agreed and most teachers agreed that communication between teachers and parents contributes to the development of the school unit efficiency. In addition, most principals and teachers did not agree to the same extent in the survey question about the contribution of guidance to the management of communication between teachers and parents (Table 2).

TABLE II: BENEFICIAL EFFECTS OF COMMUNICATION BETWEEN TEACHERS AND PARENTS (Distribution, PERCENTAGE)

\begin{tabular}{|c|c|c|c|c|c|c|c|c|c|c|c|c|c|}
\hline \multirow{2}{*}{$\begin{array}{c}\text { Beneficial } \\
\text { effects of } \\
\text { communication }\end{array}$} & \multirow[t]{2}{*}{$P^{*}$} & \multicolumn{2}{|c|}{$\begin{array}{l}\begin{array}{l}\text { Strongly } \\
\text { disagree }\end{array} \\
\end{array}$} & \multicolumn{2}{|c|}{ Disagree } & \multicolumn{2}{|c|}{$\begin{array}{c}\text { I have no } \\
\text { opinion }\end{array}$} & \multicolumn{2}{|c|}{ Agree } & \multicolumn{2}{|c|}{$\begin{array}{c}\begin{array}{l}\text { Strongly } \\
\text { agree }\end{array} \\
\text { agl }\end{array}$} & \multicolumn{2}{|c|}{$\begin{array}{l}\text { Did not } \\
\text { respond }\end{array}$} \\
\hline & & $\mathrm{N}$ & $\%$ & $\mathrm{~N}$ & $\%$ & $\mathrm{~N}$ & $\%$ & $\mathrm{~N}$ & $\%$ & $\mathrm{~N}$ & $\%$ & $\mathrm{~N}$ & $\%$ \\
\hline \multirow{2}{*}{$\begin{array}{l}\text { 1. Contributes } \\
\text { to children's } \\
\text { progress }\end{array}$} & P** & 1 & 3 & 4 & 12.1 & 1 & 3 & 18 & 54.5 & 9 & 27.3 & 0 & 0 \\
\hline & $E T^{*}$ & 1 & 0.5 & 30 & 13.5 & 29 & 13.1 & 140 & 63.1 & 21 & 9.5 & 1 & 0.5 \\
\hline \multirow{2}{*}{$\begin{array}{l}\text { 2. Improves } \\
\text { children's } \\
\text { conduct }\end{array}$} & $P$ & 1 & 3 & 4 & 12.1 & 1 & 3 & 16 & 48.5 & 11 & 33.3 & 0 & 0 \\
\hline & ET & 3 & 1.4 & 19 & 8.6 & 14 & 6.3 & 154 & 69.4 & 31 & 14 & 1 & 0.5 \\
\hline \multirow{2}{*}{$\begin{array}{l}\text { 3. Provides } \\
\text { children with } \\
\text { security }\end{array}$} & $P$ & 0 & 0 & 2 & 6.1 & 1 & 3 & 19 & 57.6 & 11 & 33.3 & 0 & 0 \\
\hline & ET & 1 & 0.5 & 11 & 5 & 31 & 14 & 142 & 64 & 36 & 16.2 & 1 & 0.5 \\
\hline \multirow{2}{*}{$\begin{array}{l}\text { 4. Contributes } \\
\text { to school } \\
\text { efficiency }\end{array}$} & $P$ & 0 & 0 & 0 & 0 & 1 & 3 & 10 & 30.3 & 22 & 66.7 & 0 & 0 \\
\hline & ET & 0 & 0 & 2 & 0,9 & 2 & 0.9 & 121 & 54.5 & 96 & 43.2 & 1 & 0.5 \\
\hline \multirow{2}{*}{$\begin{array}{l}\text { 5. Guidance } \\
\text { helps manage } \\
\text { communication }\end{array}$} & $P$ & 0 & 0 & 0 & 0 & 2 & 6.1 & 12 & 36.4 & 19 & 57.6 & 0 & 0 \\
\hline & ET & 0 & 0 & 1 & 0.5 & 22 & 9.9 & 137 & 61.7 & 61 & 27.5 & 1 & 0.5 \\
\hline
\end{tabular}

*Position, ** Principals, *** Elementary Teachers

Based on the statistical comparison of the categorical variables and the above questions (see questions 1-5, Table 2 ), there is a degree of relevance only for the categorical variables of teachers and principals with statements 4 and 5 (Table 3). Principals and teachers, with a significant degree of relevance ( significance indicator: $\mathrm{p}=0.037<0.05$ ), consider that communication between school and family contributes to the school unit efficiency. In addition, there is a strong degree of relevance $\mathrm{p}=0.003<0.01$, in the formulation of the opinion that guidance helps manage communication between teachers and parents. Statistical differences reflect the characteristics of the population.

TABLE III: OPINIONS OF TEACHERS ABOUT THE RESULTS OF COMMUNICATION BETWEEN PARENTS AND TEACHERS (STATISTICAL INDICATORS)

\begin{tabular}{|l|c|c|c|c|c|}
\hline \multirow{2}{*}{$\begin{array}{c}\text { Results of communication } \\
\text { between parents and teachers }\end{array}$} & A & SD & A & SD & \multirow{2}{*}{ t-test } \\
\cline { 2 - 5 } & \multicolumn{2}{|c|}{ Pripals } & \multicolumn{2}{|c|}{ Teachers } & \\
\hline $\begin{array}{l}\text { 4. Communication contributes } \\
\text { to school efficiency }\end{array}$ & 4.64 & 0.549 & 4.41 & 0.570 & $0.037<0.05$ \\
\hline $\begin{array}{l}\text { 5. Guidance helps manage } \\
\text { communication }\end{array}$ & 4.52 & 0.619 & 4.18 & 0.617 & $0.003<0.01$ \\
\hline
\end{tabular}

To the survey question "What are the reasons for the limited or insufficient communication between teachers and parents?", most principals and teachers agreed that the insufficient communication between parents and teachers is due to the lack of time on behalf of parents, to children's poor performance or conduct, to the fact that many parents speak a foreign language as mother tongue, have a low social and education background and cannot understand the importance of communication. Most principals disagree, while most teachers agree, that parents' insufficient communication with the school is due to parents' indifference. Moreover, most principals and teachers expressed the view that parents' insufficient communication with the school is not due to the school system structure (Table 4).

TABLE IV: REASONS FOR INSUFFICIENT OR LIMITED COMMUNICATION BETWEEN TEACHERS AND PARENTS (Distribution, PERCENTAGE)

\begin{tabular}{|c|c|c|c|c|c|c|c|c|c|c|c|c|c|}
\hline \multirow[t]{2}{*}{$\begin{array}{l}\text { Communication } \\
\text { challenges }\end{array}$} & \multirow[t]{2}{*}{$\mathrm{P}^{*}$} & \multicolumn{2}{|c|}{$\begin{array}{l}\text { Strongly } \\
\text { disagree }\end{array}$} & \multicolumn{2}{|c|}{ Disagree } & \multicolumn{2}{|c|}{$\begin{array}{c}\text { I have no } \\
\text { opinion }\end{array}$} & \multicolumn{2}{|c|}{ Agree } & \multicolumn{2}{|c|}{\begin{tabular}{|c|}
$\begin{array}{c}\text { Strongly } \\
\text { agree }\end{array}$ \\
\end{tabular}} & \multicolumn{2}{|c|}{$\begin{array}{l}\text { Did not } \\
\text { respond }\end{array}$} \\
\hline & & \begin{tabular}{l|l}
$\mathrm{N}$ \\
\end{tabular} & $\%$ & $\mathrm{~N}$ & $\%$ & $\mathrm{~N}$ & $\%$ & $\mathrm{~N}$ & $\%$ & $\mathrm{~N}$ & $\%$ & $\mathrm{~N}$ & $\%$ \\
\hline \multirow{2}{*}{$\begin{array}{l}\text { 1. Parents' lack of } \\
\text { time }\end{array}$} & C & 1 & 3 & 11 & 33.3 & 4 & 2.1 & 16 & 48.5 & 1 & 3 & 0 & 0 \\
\hline & $\mathrm{ET}^{* * *}$ & 6 & 2.7 & 35 & 15.8 & 12 & \begin{tabular}{|l|}
5.4 \\
\end{tabular} & 144 & 64.9 & 25 & 11.3 & 0 & 0 \\
\hline \multirow{2}{*}{$\begin{array}{l}2 \text { Parents' } \\
\text { indifference }\end{array}$} & $\mathrm{F}$ & 1 & 3 & 15 & 45.5 & 2 & \begin{tabular}{|l|}
6.1 \\
\end{tabular} & 13 & 39.4 & 2 & 6.1 & 0 & 0 \\
\hline & ET & 3 & 1.4 & 39 & 17.6 & 32 & \begin{tabular}{|l|}
14.4 \\
\end{tabular} & 116 & 52.3 & 8 & 12.6 & 4 & 1.8 \\
\hline \multirow{2}{*}{$\begin{array}{l}\text { 3. Children's poor } \\
\text { performance or } \\
\text { conduct }\end{array}$} & $P$ & 1 & 3 & 11 & 33.3 & 4 & 12.1 & 16 & 48.5 & 1 & 3 & 0 & 0 \\
\hline & ET & 6 & 2.7 & 54 & 24.3 & 44 & 19.8 & 98 & 44.1 & 15 & 6.8 & 5 & 2.3 \\
\hline \multirow{2}{*}{$\begin{array}{l}\text { 4. Different } \\
\text { language }\end{array}$} & P & 4 & 12.1 & 9 & 27.3 & 2 & 6.1 & 17 & 51.5 & 1 & 3 & 0 & 0 \\
\hline & ET & 7 & 3.2 & 73 & 32.9 & 26 & 11.7 & 100 & 45 & 14 & 6.3 & 2 & 0.9 \\
\hline \multirow{2}{*}{$\begin{array}{l}\text { 5. Low social and } \\
\text { education } \\
\text { background }\end{array}$} & $P$ & 3 & 9.1 & 11 & 33.3 & 4 & 12.1 & 15 & 45.5 & 0 & 0 & 0 & 0 \\
\hline & ET & 10 & 4.5 & 78 & 35.1 & 27 & 12.2 & 90 & 40.5 & 15 & 6.8 & 2 & 0,9 \\
\hline \multirow{2}{*}{$\begin{array}{l}\text { 6. Importance of } \\
\text { communication is } \\
\text { not understood }\end{array}$} & $P$ & 1 & 3 & 9 & 27.3 & 3 & 9.1 & 17 & 51.5 & 3 & 9.1 & 0 & 0 \\
\hline & ET & 7 & 3.2 & 41 & 18.5 & 17 & $\begin{array}{l}7.7 \\
\end{array}$ & 126 & 56.8 & 29 & 13.1 & 2 & 0.9 \\
\hline \multirow{2}{*}{$\begin{array}{l}\text { 7. School system } \\
\text { structure }\end{array}$} & r & 6 & 18.2 & 13 & 39,4 & 3 & 9.1 & 11 & 33.3 & 0 & 0 & 0 & 0 \\
\hline & ET & 24 & 10.8 & 122 & 55 & 27 & 12.2 & 41 & 18.5 & 6 & 2.7 & 2 & 0.9 \\
\hline
\end{tabular}

*Position, ** Principals, *** Elementary Teachers

The statistical comparison of the categorical variables and the above questions (see questions 1-7, table 4) shows a degree of relevance for the categorical variables principals/teachers, men/women, 22-30/51-60 years old, Pedagogical Academy/Department of Primary Education, 1$5 / 26$ years of experience and above, with the formulations 1 , 2, 4, 6 and 7 of the questionnaire (Table 5). The degree of statistical relevance is set to $\mathrm{p}=0.01$. According to principals and teachers, the insufficient communication of parents with teachers is due to parents' lack of time $(\mathrm{p}=0.005<0.01)$ and parents' indifference $(\mathrm{p}=0.001<0.01)$. According to teachers, both men and women, the insufficient communication between parents and teachers is due to parents' indifference $(\mathrm{p}=0.025<0.05)$. According to teachers aged 22-30 and 51-60 and above, insufficient communication is due to parents' lack of time ( $\mathrm{p}=0.004<0.05)$ as well as to the fact that some parents speak a foreign language as their mother tongue $(p=0.021<0.05)$. According to teachers whose basic studies took place at the Pedagogical Academy and the Department of Primary Education, insufficient communication is due to the fact that parents do not understand the importance of their communication with the school $(\mathrm{p}=0.017<0.05)$. Finally, teachers with experience of 1-5 years and 26 years and above, do not attribute insufficient communication to the school system structure $(\mathrm{p}=0.025<0.05)$. 
TABLE V: OPINIONS OF TEACHERS ABOUT THE INSUFFICIENT COMMUNICATION BETWEEN PARENTS AND TEACHERS (STATISTICAL INDICATORS)

\begin{tabular}{|c|c|c|c|c|c|}
\hline \multirow{2}{*}{$\begin{array}{l}\text { Insufficient communication on } \\
\text { behalf of parents because of... }\end{array}$} & A & SD & A & SD & \multirow{2}{*}{$t$-test } \\
\hline & \multicolumn{2}{|c|}{ Principals } & \multicolumn{2}{|c|}{ Teachers } & \\
\hline 1...lack of time & 3.15 & 1.034 & 3.66 & 0.965 & $0.005<0.01$ \\
\hline \multirow{3}{*}{ 2...indifference } & 3.00 & 1.118 & 3.63 & 1.016 & $0.001<0.01$ \\
\hline & \multicolumn{2}{|c|}{ Men } & \multicolumn{2}{|c|}{ Women } & \\
\hline & 3.30 & 1.126 & 3.64 & 1.008 & $0.025<0.05$ \\
\hline \multirow[b]{2}{*}{ 4...different language } & \multicolumn{2}{|c|}{ 22-30 years old } & \multicolumn{2}{|c|}{ 51-60 years old } & \\
\hline & 3.59 & 0.875 & 3.04 & 1.185 & $0.021<0.05$ \\
\hline \multirow{2}{*}{$\begin{array}{l}6 . . \text { no understanding of the } \\
\text { importance of their } \\
\text { communication with the school }\end{array}$} & \multicolumn{2}{|c|}{$\begin{array}{c}\text { Pedagogical } \\
\text { Academy* }\end{array}$} & \multicolumn{2}{|c|}{ D.P.E. ${ }^{* *}$} & \\
\hline & 1.83 & 0.769 & 2.12 & 1.058 & $0.017<0.05$ \\
\hline \multirow{2}{*}{ 7... school system structure } & \multicolumn{2}{|c|}{$\begin{array}{c}\text { Experience: } 1-5 \\
\text { years }\end{array}$} & \multicolumn{2}{|c|}{$\begin{array}{c}26 \text { years and } \\
\text { above }\end{array}$} & \\
\hline & 2.77 & 1.257 & 2.17 & 0.975 & $0.025<0.05$ \\
\hline
\end{tabular}

$* 2$ years of studies, $* * 4$ years of studies

\section{DISCUSSION OF RESULTS}

Teachers' opinions about the advantages of communication with their students' parents show that communication between teachers and parents contributes to children's progress and improves their conduct, providing also the child with a sense of security. Similar opinions appear also in the survey of Boonk et al. (2018) and Khajehpoura \& Ghazvini (2011). Research has shown that these meetings improve communication quality, positive atmosphere and efficiency in the school unit operation (Stamatis, 2019; Bennett-Conroy, 2012). Through their communication, parents connect with the school community and in this way a positive atmosphere of trust, confidentiality and empathy is developed between them, benefiting both the child and school (Ozmen et al., 2016; Jeynes, 2005). Peña (2000) holds that students' school performance and conduct improve when teachers communicate personally with parents, by phone or email or through written updates. Moreover, inviting parents to visit the school or classroom create a positive setting for parents' participation in the education process (Griffith, 1988) and form the basis for a constructive communication between school and family (Adams \& Christenson, 2000).

According to teachers, within the framework of this survey, it seems that School Guidance can support parents, children and teachers, offering them the possibility to come closer and have a positive and supportive mind-set about their competences, in a context of mutual respect and understanding. According to studies, this can be achieved through school meetings, events and dialogue (Mata et al., 2018).

The study of Konsolas, Stamatis \& Darsinos (2012) reports that for a more efficient communication between school and family in dealing mostly with conflictual situations, the school unit should have a child psychologist. The sessions of the child psychologist with the children's parents would contribute to a sincere, counselling, mutual provision of information about the children's challenges and possibilities. Within the framework of developing a communication culture and in order to achieve cooperation in all aspects of school life, "specialized training of teachers, seminars at schools for parents and a series of special information meetings" (Stamatis, 2013:322) are proposed, to the benefit of the school unit efficiency.

Based on the opinions of the teachers who participated in this study, it becomes obvious that the insufficient communication between parents and the school unit attended by their children is not due to the school system structure. Teachers attributed the insufficient communication between parents and teachers to the lack of time on behalf of parents, to the low social and education background of parents, to the poor performance or conduct of their children and to the fact that many parents speak a foreign language as their mother tongue.

In addition, according to the views expressed by teachers, many parents refuse to understand the importance of communication between teachers and parents. Views of teachers expressed in similar studies about communication challenges refer to social and financial reasons (Hair et al. 2015; Cooper et al 2009; Hill \& Taylor, 2004), which have an impact on the communication between parents and teachers, such as the type of profession and parents' working hours (Hornby \& Blackwell, 2018).

The views of teachers regarding the advantages and reasons hindering their communication with parents do not seem to be significantly different in relation to their position, gender, age, years of experience and studies. The studies of Brandon (2009) and Wright (2009), who examined teachers' views about parents' participation in the education process in relation to their gender and years of experience reached the conclusion that women and older teachers considered more important the communication with parents.

\section{CONCLUSIONS}

1) The conclusions of this study based on the survey questions presented in Section 2 are the following:

2) Primary education teachers mention that the advantages of communication between teachers and parents have a positive impact on the children and school unit attended by them, as children improve their performance and conduct in a safe school environment.

3) School Counselling is viewed as important by teachers, as it can support parents, children and teachers and improve communication among them.

4) Many parents do not communicate with their children's teachers due to increased workload or for reasons relating to their educational, social and financial background or even because of their inability to understand the Greek language because they have a different nationality.

5) The views of teachers about the advantages and challenges of their communication with parents do not seem to differ significantly in relation to their position, gender, age, years of experience and studies.

\section{PROPOSALS}

Based on the results of this study, communication between teachers and parents plays an important part in the improvement of children's school performance and conduct as well as in the improvement of the school efficiency. For this reason, it is proposed to study in the future, more adequately and more extensively, more aspects concerning communication between teachers and parents, forms and practices followed by teachers in their communication with 
parents, as well as teachers' training in issues of communication with the parents of their students.

\section{LIMITATIONS}

Although the number of questionnaires and the percentage of participation of teachers in this survey was satisfactory, the results were not compared with other regions and focused on one geographical region only. In addition, the sample is limited to a specific specialization, since all the principals and teachers who participated belong to the same specialization. Therefore, the conclusions of this study cannot be generalized. However, they show trends that are particularly interesting and useful in educational design.

\section{ACKNOWLEDGMENT}

Sincere acknowledgements to the teachers who dedicated their valuable time to fill in the questionnaire. Their views constituted the basis of this study.

\section{REFERENCES}

[1] K. S. Adams and S. L. Christenson, "Trust and the family-school relationship: Examination of parent-teacher differences in elementary and secondary grades". Journal of School Psychology, vol. 38, no. 5, pp. 477-497, 2000.

[2] J. Attanucci, "Questioning honor: a parent-teacher conflict over excellence and diversity in a USA urban high school". Journal of Moral Education, vol. 33, no.1, pp. 57-69, 2004.

[3] W. Bennett-Conroy, "Engaging Parents of Eighth Grade Students in Parent- Teacher Bidirectional Communication", School Community Journal, vol. 22, no.2, pp. 87-110, 2012.

[4] L. Boonk, H. J., Gijselaers, H. Ritzen and S. Brand-Gruwel, “A review of the relationship between parental involvement indicators and academic achievement”, Educational Research Review, vol. 24, pp. 10-30, 2018.

[5] G. Brandon, "Middle School Teacher and parent Perceptions of Parental Involvement", Unpublished doctoral Dissertation, Western Michigan University, UMI Number: 3354069, 2009.

[6] U. Bronfenbrenner, "Ecology of the family as a context for human development: Research perspectives", Developmental Psychology, vol. 22, pp. 273-742, 1986.

[7] M. Castro, E. Expósito-Casas, E. López-Martín, L. Lizasoain, E. Navarro-Asencio and J. L. Gaviria, "Parental involvement on student achievement: A metanalysis", Educational Research Review, vol. 14 pp. 33-46, 2015.

[8] C. E. Cooper, R. Crosnoe, M. A. Suizzo and K. A.Pituch, K. A., "Family poverty, race, and the involvement of parents in early education" Journal of Family Journal of Family, vol. 31, no. 7, pp. 1$12,2009$.

[9] J. L. Epstein, "School/Family/Community partnerships: Caring for the children we share", The Phi Delta Kappa, vol. 76, no. 9, pp. 701-712, 1995.

[10] J. L. Epstein, "Improving family and community involvement in secondary schools” Principal Leadership, vol. 8, no. 2, pp. 16-22, 2008.

[11] J. L. Epstein, School, family, and community partnerships: Preparing educators and improving schools, Routledge, 2018.

[12] M. Grace and A. C. Gerdes, "Parent-teacher relationships and parental involvement in education in Latino families", Contemporary School Psychology, vol. 23, no. 4, pp. 444-454, 2019.

[13] J. Griffith, "The relation of school structure and social environment to parent involvement in elementary schools", The Elementary School Journal, vol. 99, no. 1, pp. 53-80, 1998.

[14] N. L. Hair, L. J. Hanson, B. L. Wolfe and S. D. Pollak, "Association of child poverty, brain development, and academic achievement", JAMA Pediatr, vol. 169, no. 9, pp. 822-829, 2015.

[15] N. E. Hill and L. C. Taylor, "Parental school involvement and children's academic achievement", American Psychological Society, vol. 13, no. 4, pp. 161-164, 2004.

[16] K. Hoover-Dempsey, J. Walker, H. M. Sandler and D. Whetsel, "Why do parents become involved? Research findings and implications", Elementary School Journal, vol. 106, no. 2, pp. 105-130, 2005.
[17] G. Hornby and I. Blackwell, "Barriers to parental involvement in education: An update", Educational Review, vol. 70, no. 1, pp. 109$119,2018$.

[18] A. J. Houtenville and K. S. Conway, "Parental effort, school resources, and student achievement", Journal of Human resources, vol. 43, no. 2, pp. 437-453, 2008.

[19] W. H. Jeynes, "The Effects of Parental Involvement on the Academic Achievement of African American Youth", Journal of Negro Education, vol. 74, no. 3, pp. 260-274, 2005.

[20] W. H. Jeynes, "A Meta-analysis: The relationship between father involvement and student academic achievement", Urban Education, vol. 50, no. 4, pp. 387-423, 2015.

[21] W. H. Jeynes, "A meta-analysis: The relationship between parental involvement and African American school outcomes", Journal of Black Studies, vol. 47, no. 3, pp. 195-216, 2016.

[22] M. Khajehpoura and S. D. Ghazvini, "The role of parental involvement affect in children's academic performance" Procedia Social and Behavioral Sciences, vol. 15, pp. 1204-1208, 2015.

[23] L. Kidder and C. Judd, "Research methods in social relations", Chicago: Holt, Rinehart and Winston Inc, 1986.

[24] M. Konsolas, P. Stamatis and K. Darsinos, K. "The contribution of communication to the management of educational crises: Views of Teachers about their Communication with Parents", In F. Kalavasis and A. Kontakos (Eds.), Issues of Educational Design: "Questions of Educational Design: Crisis Management and Governance of School Units", vol. 5, pp. 130-139, Athens: Diadrasi Publications, 2012.

[25] M. A. Lawson, "School-family relations in context - parent and teacher perceptions of parent involvement", Urban Education, vol. 38, no. 1, pp. 77-133, 2003.

[26] M. Linardakis, (2014). P-value. Correlation factors. [Online]. Available:

https://opencourses.uoc.gr/courses/mod/page/view.php?id=6671.

[27] L. Mata, I. Pedro and F. J. Peixotoa, "Parental support, student motivational orientation and achievement: The impact of emotions", International Journal of Emotional Education, vol. 10, no. 2, pp. 7792, 2018.

[28] I. Matsagouras and M. Poulou, "School-family relations, comparative presentation of teachers' and parents' views", Mentor, vol. 11, pp. 2741, 2009.

[29] R. Oostam and E. Hooge, "Making the difference with active parenting; forming educational partnerships between parents and schools", European Journal of Psychology of Education, vol. 28, no. 2, pp. 337$351,2012$.

[30] M. Otani, "Relationships between parental involvement and adolescents' academic achievement and aspiration", International Journal of Educational Research, vol. 94, pp. 168-182, 2019.

[31] A. N. Owen, (2016). Forming collaborative parent-teacher relationships to increase parental involvement Independent Studies and Capstones, pp. $728 . \quad$ [Online]. Available: https://digitalcommons.wustl.edu/pacs_capstones/728.

[32] F. Ozmen, C. Akuzum, M. Zincirli and G. Selcuk, "The Communication Barriers between Teachers and Parents in Primary Schools", Eurasian Journal of Educational Research, vol. 66, pp. 2746, 2016.

[33] D. C. Peña, "Parent involvement: Influencing factors and implications" The Journal of Educational Research, vol. 94, no. 1, pp. 42-54, 2000.

[34] B. Ryan, and G. Adams, "The family-school relationships models", In Ryan, B., Adams, G. et al (Eds.), The family school connection, pp. 328). Thousand Oaks, CA: Sage Publications, 1995.

[35] P. J. Stamatis, Communication education, Athens: Diadrasi Publications, 2013.

[36] P. J. Stamatis, "Communication relations among parents and preschoolers: Thoughts, comments and suggestions", In R. V. Nata (Ed.), Progress in Education, vol. 60, pp. 83-106, USA, NY: Nova Science Publishers, 2019.

[37] P. J. Stamatis and E. N. Nikolaou, Communication and Mental Health Promotion in Early Childhood Education USA, NY: Nova Science Publishers, 2020.

[38] P. J. Stamatis and A. Papanikolaou, A., "Environmental influences in communication of Greek family: A comparative case study", In D. M., Kakana and P. Manoli (Eds.), Digital Proceedings from the 3rd International Symposium on New Issues on Teacher Education-ISNITE 2015, pp. 327-333, Volos: University of Thessaly Press, 2017.

[39] C. Y. Tan, M. Lyu, M. and B. Peng, B. (2019). Academic benefits from parental involvement are stratified by parental socioeconomic status: A meta-analysis. Parenting. [Online]. Available: https://doi.org/10.1080/15295192.2019.1694836

[40] A. M. Thompson, K. C. Herman, M. A. Stormont, W. M. Reinke and C. Webster-Stratton, "Impact of Incredible Years on teacher 
perceptions of parental involvement: A latent transition analysis", Journal of School Psychology, vol. 62, pp. 51-65, 2017.

[41] S. Wilder, "Effects of parental involvement on academic achievement: A meta-synthesis", Educational Review, vol. 66, no. 3, pp. 377-397, 2014.

[42] T. Wright, T., "Parent and Teacher Perceptions of Effective Parental Involvement", Unpublished doctoral dissertation Presented to The Faculty and School of Education Liberty University. UMI Number: 3368956, 2009.

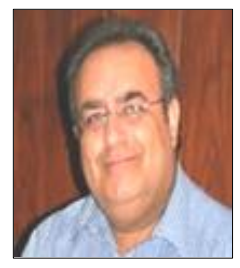

Panagiotis J. Stamatis is Associate Professor of Communication Education in Preschool and Early Primary School Education in the Department of Sciences of Preschool Education and Educational Design, University of the Aegean, Greece. At the same university he studied the Sciences of Preschool and Elementary School Education and he completed his $\mathrm{PhD}$ studies with honors in Pedagogical Communication putting emphasis on Nonverbal Communication in Preschool Education. Since 1989 to 2012 he worked in Primary School Education (PSE), reaping great teaching and administrative experience. He left PSE while he was an Elementary School Teachers' Counselor.

He has participated in many conferences as delegate and/or member of several scientific and organizing committees, in educational and research projects and teachers' training programs. He has published pedagogical books in Greece and USA, himself and/or in collaboration. Also, he has reviewed and published several articles in journals, conference proceedings and book chapters. He has given lectures in various institutions and universities. He is a member of the Greek Pedagogical Association and awarded for his writings and social contribution.

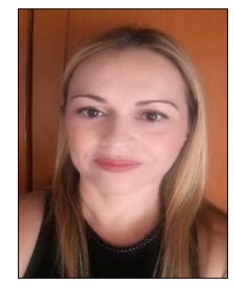

Maria E. Chatzinikola is a Primary Education teacher born in Rhodes Island, Greece. She holds a bachelor degree from the Department of Primary Education of the University of the Aegean (1994). Also, she holds a Postgraduate Training Diploma in Primary Education from "Alexandros Delmouzos" Teachers' Training Institute (2011) and a Master's Degree in Models of Educational Planning and Development from the Department of Sciences Preschool Education and Educational Design, University of the Aegean (2019). Currently, she is a PhD student in the field of Nonverbal Communication. 